\title{
Pengaruh Model Pembelajaran Role Reversal Question Berbantuan Media Audio Visual Terhadap Kompetensi Pengetahuan PPKn
}

\author{
Ni Wayan Prawi Santi ${ }^{*}$, Made Putra², I.B Gede Surya Abadi ${ }^{3}$ \\ ${ }^{123}$ Program Studi Pendidikan Guru Sekolah Dasar, Universitas Pendidikan Ganesha, Singaraja, Indonesia
}

\begin{abstract}
Abstrak
Penelitian ini bertujuan untuk mengetahui pengaruh yang signifikan kompetensi pengetahuan PPKn antara kelompok siswa yang dibelajarkan menggunakan model Role Reversal Question berbantuan media Audio Visual dan kelompok siswa yang dibelajarkan menggunakan pembelajaran konvensional pada siswa kelas V. Jenis penelitian ini adalah penelitian kuantitatif dengan desain quasi eksperiment (Eksperimen Semu). Desain eksperimen yang digunakan dalam penelitian ini adalah Nonequivalent Control Group Design. Populasi dalam penelitian ini berjumlah 268 siswa. Penentuan sampel dilakukan dengan teknik Cluster Random Sampling. Metode pengumpulan data yang digunakan adalah metode tes dengan jenis tes objektif. Data yang dikumpulkan berupa nilai penguasaan kompetensi pengetahuan PPKn dianalisis dengan uji t. Dari sebaran data, diperoleh rata-rata kompetensi pengetahuan PPKn kelompok eksperimen yaitu 85,41 sedangkan kelompok kontrol yaitu 81,38. Berdasarkan hasil analisis data, diperoleh thitung $=$ 2.166 dan ttabel $=2.019$ pada taraf signifikansi $5 \%$ dengan $\mathrm{dk}=41$. Oleh karena thitung > ttabel $(2.166>2.019)$ maka Ho ditolak, hal itu berarti tidak terdapat perbedaan yang signifikan kompetensi pengetahuan PPKn antara kelompok siswa yang dibelajarkan menggunakan model pembelajaran Role Reversal Question berbantuan Media Audio Visual dengan kelompok siswa yang dibelajarkan menggunakan pembelajaran konvensional pada kelas V SD. Jadi dapat disimpulkan bahwa model pembelajaran Role Reversal Question berbantuan Media Audio Visual berpengaruh terhadap kompetensi pengetahuan PPKn pada siswa kelas V SD. Implikasi dari penelitian ini yaitu memberikan masukan bagi sekolah tersebut dengan menentukan kebijakan berupa penerapan model pembelajaran yang inovatif dalam pelaksanaan pembelajaran.
\end{abstract}

\begin{abstract}
This study aims to determine the significant influence of PPKn knowledge competence between groups of students who are taught using the Role Reversal Question model assisted by Audio Visual media and groups of students who are taught using conventional learning in fifth grade students. This type of research is quantitative research with quasi experimental design (Experiments) Pseudo). The experimental design used in this study was Nonequivalent Control Group Design. The population in this study amounted to 268 students. Determination of the sample is done by the cluster random sampling technique. Data collection method used is a test method with the type of objective test. Data collected in the form of mastery competency value of PPKn knowledge were analyzed by test. From the data distribution, obtained the average competency of PPKn knowledge in the experimental group was 85.41 while the control group was 81.38. Based on the results of data analysis, obtained tcount $=2.166$ and ttable $=2.019$ at a significance level of $5 \%$ with $\mathrm{dk}=41$. Because tcount $>$ ttable $(2.166>2,019)$ then Ho is rejected, it means that there is no significant difference in the competence of PPKn knowledge between groups students who are taught using the Role Reversal Question learning model assisted by Audio Visual Media with groups of students who are taught using conventional learning in the fifth grade elementary school. So it can be concluded that the Role Reversal Question learning model assisted by Audio Visual Media influences the competence of PPKn knowledge in fifth grade elementary school students. The implication of this research is to provide input for these schools by determining policies in the form of the application of innovative learning models in the implementation of learning.
\end{abstract}

\footnotetext{
* Corresponding author. 


\section{PENDAHULUAN}

Pengembangan kurikulum terus dilakukan pemerintah dalam upaya untuk meningkatkan kualitas dan mutu pendidikan di Indonesia. Kurikulum disusun untuk mewujudkan tujuan pendidikan nasional dengan memperhatikan tahap perkembangan siswa. Kurikulum yang sedang dikembangkan pemerintah di Indonesia saat ini adalah kurikulum 2013 yang merupakan hasil pengembangan Kurikulum Tingkat Satuan Pendidikan (KTSP). Pendidikan formal merupakan satuan pendidikan di Indonesia, menurut Undang-Undang Republik Indonesia Nomor 20 Tahun 2003 pasal 1 tentang Sistem Pendidikan Nasional, diartikan bahwa sebagai kelompok layanan pendidikan pada jalur formal, nonformal dan informal ada setiap jenjang dan jenis pendidikan. Pendidikan formal terdiri dari pendidikan dasar, pendidikan menengah dan pendidikan tinggi.

Seiring dengan perkembangan ilmu pengetahuan dan teknologi, maka secara otomatis pola pikir masyarakat berkembang dalam setiap aspek. Hal ini sangat berpengaruh terutama dalam dunia pendidikan yang menuntut adanya inovasi baru yang dapat menimbulkan perubahan secara kualitatif yang berbeda dengan sebelumnya. Jika pendidikan merupakan salah satu instrumen utama pengembangan SDM, tenaga pendidik dalam hal ini guru sebagai salah satu unsur yang berperan penting di dalamnya, memiliki tanggung jawab untuk mengembangkan tugas dan mengatasi segala permasalahan yang muncul. Masalah krusial yang dihadapi dunia pendidikan saat ini adalah lemahnya proses pembelajaran, dalam proses pembelajaran siswa kurang didorong untuk mengembangkan keterampilan berpikir. Di dalam kelas siswa hanya diarahkan untuk menghapal informasi, siswa menjadi terbiasa untuk mengingat dan menimbun informasi yang didapatkan tanpa berusaha untuk menghubungkan yang diingat itu dengan kehidupan sehari-hari (kontekstual). Keberhasilan implementasi suatu strategi pembelajaran di dalam kelas tergantung pada kepiawaian guru dalam menggunakan model, metode, media, teknik dan strategi pembelajaran tersebut.

Pelaksanaan pembelajaran di kelas perlu didesain menjadi pembelajaran yang menyenangkan dan membuat siswa tertarik mengikuti pembelajaran. Namun pada kenyataannya, dalam proses pembelajaran di sekolah dasar terutama menyangkut bidang PPKn masih banyak kelemahan yang ditemukan dilihat dari hasil belajar PPKn siswa terutama pada kompetensi pengetahuan. Pembelajaran belum sepenuhnya berpusat pada siswa, siswa belum sepenuhnya aktif dalam menyampaikan pendapat atau gagasannya, siswa kurang kreatif dan kurang memiliki motivasi dalam mengikuti kegiatan pembelajaran. Hal tersebut sesuai dengan informasi yang diperoleh dari wawancara dengan beberapa guru dan siswa di SD Gugus III Kecamatan Klungkung, dikatakan bahwa pembelajaran di kelas masih didominasi oleh guru dan siswa masih banyak yang merasa belum percaya diri untuk berani mengemukakan pendapat atau gagasannya di depan kelas.

Usaha bidang pendidikan untuk peningkatan kualitas dan hasil belajar siswa tidak terlepas dari berbagi faktor yang mempengaruhinya. Dalam hal ini diperlukan guru-guru kreatif yang dapat membuat pembelajaran menjadi lebih menarik dan disukai oleh siswa. Tidak hanya itu, guru juga harus mampu menggunakan pembelajaran yang mengaktifkan siswa. Atmosfer kelas perlu dibangun sedemikian rupa dengan menggunakan model pembelajaran yang tepat agar siswa dapat memperoleh kesempatan untuk berinteraksi dan bekerja sama satu sama lain, sehingga siswa menjadi lebih berkualitas dan hasil belajar lebih optimal. Model pembelajaran yang dapat diterapkan untuk mengatasi masalah di atas adalah model pembelajaran aktif. Penerapan model pembelajaran aktif akan lebih efektif apabila didukung dengan media audio visual.

Pembelajaran aktif merupakan sebuah upaya yang mempunyai tujuan menciptakan suasana pembelajaran yang aktif. Siswa menjadi subjek pendidikan yang dituntut aktif dalam proses pembelajaran di kelas. "Pembelajaran aktif secara sederhana didefinisikan sebagai metode pengajaran yang melibatkan siswa secara aktif dalam proses pembelajaran" (Warsono \& Hariyanto, 2012:12). Pembelajaran aktif mengkondisikan agar siswa selalu melakukan pegalaman belajar yang bermakna dan senantiasa berpikir tentang apa yang dapat dilakukannya selama pembelajaran. Dari pengertian tersebut dapat diketahui bahwa pembelajaran aktif merupakan kegiatan belajar yang mengaktifkan siswa, dalam artian siswa terlibat langsung dalam pembelajaran yang berhubungan dengan aspek kognitif, afektif dan psikomotorik.

Berdasarkan penjelasan sebelumnya dapat diketahui keunggulan model pembelajaran aktif yaitu siswa turut aktif dalam kegiatan pembelajaran, siswa menggunakan segala potensi yang dimiliki dalam proses belajar. Penggunaan model pembelajaran aktif menjadikan pembelajaran berpusat pada siswa bukan berpusat pada guru. Keunggulan lain dari pembelajaran aktif yaitu dapat memupuk sikap siswa untuk dapat berfikir kritis tentang materi yang dipelajari.

"Ada berbagai tipe pembelajaran aktif yang menekankan pada kegiatan tanya jawab yaitu starts with a question, role reversal question dan planted question". Dalam penelitian ini, peneliti tertarik menggunakan tipe role reversal question. "Role reversal question merupakan suatu model pembelajaran 
yang memberikan kesempatan para siswa untuk bertukar peran menjadi guru sehingga setiap siswa akan tertantang dan berlatih menjelaskan permasalahan kepada teman-temannya" Silberman (dalam Sari, 2018). "Penerapan role reversal question lebih menekankan melakukan tanya jawab dengan bertukar peran" Silberman (dalam Murti, 2016) Kegiatan tanya jawab dapat membantu siswa untuk memperoleh pengetahuan, keterampilan dan keaktifan dalam belajar. Melalui proses tanya jawab dapat memudahkan siswa untuk memahami materi, menjadikan siswa aktif dan dapat meningkatkan hasil belajar. Melalui model ini juga, siswa dapat berpartisipasi secara langsung tidak hanya mendengarkan penjelasan materi yang di sampaikan oleh guru namun juga berfikir kritis dalam tanya jawab mengenai materi pembelajaran yang dipelajari.

Model pembelajaran role reversal question jika dipadukan dengan media pembelajaran audio visual akan lebih efektif diterapkan. "Media audio visual adalah media yang mempunyai unsur suara dan unsur gambar, sehingga untuk menikmatinya diperlukan indera pendengaran dan pengelihatan" (Tegeh \& Kirna, 2010:94). Sedangkan menurut Supradnyana (2016) media audio visual tepat digunakan dalam pembelajaran di kelas untuk menarik dan merangsang minat karena media audio visual lebih mampu mengembangkan pengetahuan siswa, bervariasi, memberikan suasana yang berbeda, mengembangkan imajinasi dan tidak membuat siswa merasa jenuh dalam mengikuti pelajaran. Berdasarkan pendapat tersebut dapat dirangkum bahwa media audio visual adalah media yang mempunyai unsur suara dan unsur gambar. Jenis media ini mempunyai kemampuan yang lebih baik, karena meliputi kedua jenis media auditif (mendengar) dan visual (melihat).

Paparan tersebut menunjukkan bahwa pemilihan model pembelajaran sangat penting guna disesuaikan dengan karakteristik pokok bahasan dan karakteristik siswa, sehingga model pembelajaran yang dipilih dapat meningkatkan pemahaman siswa terhadap materi pelajaran, meningkatkan berbagai keterampilan termasuk berfikir kritis dalam menjawab suatu pertanyaan dan meningkatkan berbagai.

Hasil temuan pada penelitian ini memiliki persamaan dengan penelitian sebelumnya yang relevan dan memperkuat hasil penelitian yang diperoleh. Hasil penelitian yang relevan tersebut, yaitu penelitian yang dilakukan oleh Sari (2018). Berdasarkan hasil penelitian menunjukkan bahwa model role reversal questions (bertukar peran membuat pertanyaan) berpengaruh terhadap hasil belajar siswa kelas V pada mata pelajaran PKn di SDN gugus V Kecamatan Cakranegara tahun pelajaran 2017/2018. Dan penelitian yang dilakukan oleh Indriani (2015) menyimpulkan bahwa pembelajaran PKn menggunakan model active learning tipe role reversal question dapat meningkatkan hasil belajar peserta didik kelas V SD N Minomartani 6 Sleman Yogyakarta.

Dari uraian sebelumnya tentang karakteristik model pembelajaran role reversal question dan media audio visual penulis memilih "Pengaruh Model Pembelajaran Role Reversal Question Berbantuan Media Audio Visual terhadap Kompetensi Pengetahuan PPKn Siswa Kelas V SD Gugus III Kecamatan Klungkung" sebagai materi yang akan dibahas dalam tulisan ini.

\section{METODE PENELITIAN}

Penelitian ini dilakukan pada bulan Januari sampai dengan bulan Maret 2020 di kelas V SD Gugus III Kecamatan Klungkung tahun ajaran 2019/2020. Jenis penelitian ini adalah penelitian kuantitatif dengan desain eksperimental yaitu desain eksperimen semu (quasi experiment design). Jenis penelitian yang dilakukan dalam penelitian ini adalah penelitian kuantitatif dengan desain eksperimental yaitu quasi eksperiment (Eksperimen Semu). Desain eksperimen yang digunakan dalam penelitian ini adalah Nonequivalent Control Group Design. Dalam desain ini terdapat dua kelompok sampel yang terdiri dari kelompok eksperimen dan kelompok kontrol sebagai subjek penelitian yang dibandingkan. Bentuk desain quasi eksperimen yang digunakan adalah "Nonequivalent control group design", ilustrasinya sebagai berikut:

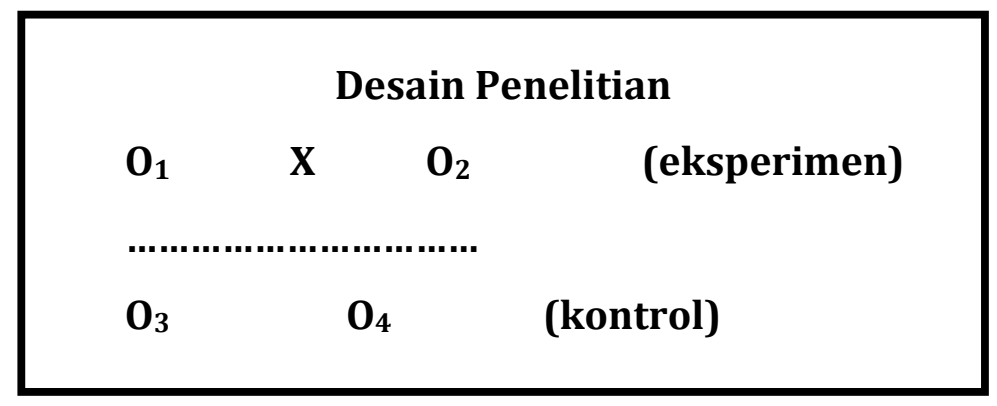

Gambar 1. Rancangan Penelitian 
Prosedur penelitian yang dilalui dalam penelitian ini meliputi 3 tahapan, yaitu tahap persiapan, tahap pelaksanaan, dan tahap akhir penelitian. Pada tahap persiapan penelitian, terlebih dahulu mengadakan atau mempersiapkan hal-hal seperti; (a) wawancara terkait penelitian, (b) penyusunan Rancangan Pelaksanaan Pembelajaran (RPP), (c) mendiskusikan RPP bersama dosen pembimbing dan wali kelas, (d) menyiapkan perangkat perangkat pendukung, sebagai media pembelajaran, serta (e) Mendiskusikan instrument penelitian untuk pengumpulan data bersama dosen pembimbing dan wali kelas. Pada tahap pelaksanaan penelitian dilakukan pemberian perlakuan sebanyak 6 kali kepada kelompok eksperimen dengan model pembelajaran Role Reversal Question berbantuan media audio visual, sedangkan kelompok kontrol tetap dibelajarkan secara konvensional. Sementara, pada akhir penelitian diberikan posttest untuk mengukur kompetensi pengetahuan PPKn pada kedua kelompok, yang kemudian dilanjutkan dengan pengolahan data.

Suatu penelitian tidak terlepas dari subjek atau objek yang diteliti. Pada penelitian ini subjek penelitian disebut dengan populasi dan sampel penelitian. Populasi merukapan wilayah generalisasi dari objek/subjek berdasarkan karakteristik tertentu yang ditetapkan untuk dipelajari dan ditarik kesimpulannya (Sugiyono, 2018). Menurut (Setyosari, 2015:221), "Populasi merupakan kelompok yang lebih besar jumlahnya dan biasanya yang dipakai untuk menggeneralisasikan hasil penelitian". Dari pengertian tersebut dapat disimpulkan bahwa populasi adalah keseluruhan obyek/subyek dalam penelitian yang mempunyai kualitas dan karakteristik tertentu yang diterapkan oleh peneliti untuk dipelajari dan kemudian ditarik kesimpulannya. Populasi dalam penelitian ini adalah seluruh siswa kelas V SD Gugus III Kecamatan Klungkung tahun ajaran 2019/2020 yang secara keseluruhan berjumlah 268 siswa dari 10 kelas dalam 7 sekolah.

Setelah menentukan populasi penelitian, selanjutnya menetapkan anggota sampel yang terlibat langsung dalam penelitian. Menurut Sugiyono (2018: 118) menyatakan bahwa "sampel adalah bagian dari jumlah dan karakteristik yang dimiliki oleh populasi tersebut". Sampel adalah bagian dari populasi untuk mewakili penelitian yang ditentukan dengan teknik tertentu (Agung, 2014). Dari pengertian tersebut, dapat disimpulkan bahwa sampel adalah sebagian populasi yang diambil untuk mewakili seluruh populasi dengan teknik tertentu. Penentuan sampel penelitian menggunakan teknik tertentu disebut dengan teknik sampling.

Teknik sampling yang digunakan untuk menentukan sampel dalam penelitian ini adalah random sampling. Random sampling merupakan salah satu teknik pengambilan sampel yang dilakukan dengan memberikan kesempatan yang sama kepada anggota populasi untuk terpilih menjadi sampel penelitian (Sugiyono, 2018). Random sampling yang digunakan adalah Cluster Random Sampling. Cara ini digunakan apabila populasi atau sampel yang tersedia adalah berupa unit-unit rumpun dalam populasi (Setyosari, 2012:191). Teknik ini biasa dipakai oleh para peneliti, karena tidak mungkin bila dilakukan teknik acak atau rambang. Penelitian eksperimental tentang pengaruh metode mengajar biasanya menggunakan kelas-kelas atau kelompok-kelompok, dan tidak mungkin mengambil secara acak setiap individual anak dari setiap kelas. Sebelum menentukan kelompok eksperimen dan kelompok kontrol, anggota sampel penelitian diberikan tes uji kesetaraan terlebih dahulu yang bertujuan untuk mengetahui kesetaraan sampel secara akademik. Berdasarkan hasil pengundian diperoleh kelas V SD Negeri 3 Semarapura Klod dengan 22 siswa sebagai kelompok eksperimen dan kelas V SD Negeri 2 Semarapura Klod Kangin dengan 21 siswa sebagai kelompok kontrol. Penyetaraan kelompok dilakukan menggunakan uji-t. Data yang digunakan dalam uji kesetaraan adalah nilai pretest yang telah diberikan. Perlakuan yang diberikan pada kelompok eksperimen berupa model pembelajaran Role Reversal Question Berbantuan Media Audio Visual sedangkan kelompok kontrol tidak diberikan perlakuan apapun melainkan dibelajarkan secara konvensional.

Penelitian ini tidak terlepas dari kontrol validitas internal dan eksternal. Kontrol validitas internal merupakan faktor yang bersumber dari pelaksanaan penelitian itu sendiri yang berkaitan dengan perlakuan yang diberikan, apakah benar-benar mempengaruhi hasil dalam penelitian atau tidak. (Setyosari, 2015). Validitas internal dalam penelitian ini meliputi; (1) bias seleksi, bias seleksi sering terjadi dalam eksperimen, artinya bahwa kelompok eksperimen mungkin telah memiliki dorongan kuat untuk berhasil atau kemampuan untuk mencapai keberhasilan sebelum dilancarkannya eksperimen. (2) kematangan atau maturasi (maturation), kematangan berkaitan dengan perubahan subjek, perubahan yang terjadi pada subjek dikarenakan pengaruh waktu, bukan disebabkan oleh perlakuan yang diberikan sehingga dapat memberi pengaruh pada hasil eksperimen (Dantes, 2012). (3) sikap subjek, sikap subjek ini merupakan salah satu ancaman dalam penelitian. Dalam sebuah penelitian dapat terjadi subjek mengetahui dirinya dijadikan partisipan dalam suatu kegiatan eksperimen sehingga akan muncul perasaan bangga karena ada yang memperhatikan, terlebih jika diketahui bahwa penelitian ini adalah untuk memperbaiki keadaan subjek. (4). karakteristik subjek, pemilihan sampel penelitian secara kelompok ataupun perorangan yang dapat menghasilkan kelompok yang tidak homogen yang tidak 
diinginkan, tetapi memiliki keterkaitan denga variabel yang diteliti. Karakteristik subjek yang dapat menyebabkan bias seleksi, yaitu seperti umur, kecepatan, daya tahan, intelegensi, bahasa, sikap, kelancaran bicara, status social ekonomi dan keyakinan. (5) sejarah, "istilah sejarah merujuk pada peristiwa yang terjadi disekitar atau lingkungan pada saat yang sama ketika variabel eksperimental tersebut dilakukan melalui pengujian" (Setyosari, 2015:180). (6) pengaruh penggunaan istrumen, Setyosari (2015:186) mengemukakan bahwa, "instrumenasi (instrumentation) adalah pengukuran atau prosedur observasi yang dipakai selama pelaksanaan perlakuan". Prosedur ini dilakukan dengan cara pemberian tes. Instrumen ini merujuk pada suatu kenyataan bahwa perbedaan yang sedang diobservasi dalam suatu variabel terikat dapat terjadi pada perlakuan itu sendiri.

Sementara itu, Validitas eksternal merupakan faktor yang dapat mempengaruhi hasil penelitian yang bersumber dari luar penelitian itu sendiri serta mengarah kepada sejauh mana suatu hasil penelitian dapat digeneralisasikan. Sejalan dengan pendapat Setyosari (2015), yakni validitas eksternal merujuk pada generalisasi atau representasi temuan-temuan penelitian dan berkenaan dengan seberapa jauh dapat menggeneralisasikan hasil penelitian diluar penelitian. Dengan demikian, validitas eksternal menunjukkan seberapa representatif hasil penelitian digeneralisasikan pada populasinya. Ancaman validitas eksternal yang diperhatikan serta cara mengatasi dalam penelitian ini adalah interaksi antara seleksi subjek dengan perlakuan. Beberapa faktor yang berkaitan dengan validitas eksternal diantaranya interaksi antara perlakuan dan orang, interaksi antara perlakuan dan latar serta interaksi antara perlakuan dan waktu. Istilah interaksi merupakan suatu kombinasi perlakuan dengan orang, latar dan waktu bukannya dengan perlakuan itu sendiri yang menyebabkan perbedaan hasil. Cara yang dapat dilakukan untuk mengontrol validitas eksternal pada penelitian ini yaitu dengan cara menggunakan kontrol yang memiliki kesamaan dengan kelompok eksperimen dari segi eksternal.

Metode pengumpulan data yang digunakan dalam penelitian ini adalah metode tes. Menurut Arikunto (2013:67) "Tes merupakan alat atau prosedur yang digunakan untuk mengetahui atau mengukur sesuatu dalam suasana, dengan cara atau aturan-aturan yang sudah ditentukan". Instrumen yang digunakan berupa tes. Jenis tes yang digunakan dalam penelitian ini adalah jenis tes objektif dalam bentuk pilihan ganda (Multiple Choice). Tes yang digunakan untuk mengukur kompetensi pengetahuan PPKn siswa berupa tes objektif dalam bentuk pilihan ganda biasa. Sebelum digunakan, terlebih dahulu tes divalidasi secara teoretis dengan menyusun kisi-kisi dan mengadakan konsultasi dengan ahli dibidangnya, selanjutnya dilakukan validasi secara empiris dengan mengujicobakan instrumen kepada siswa di kelas yang lebih tinggi.

Sebelum tes digunakan, terlebih dahulu dilakukan pengujian kelayakan instrumen yang digunakan untuk mengukur kompetensi pengetahuan PPKn siswa yang meliputi uji validitas, uji daya beda, uji tingkat kesukaran dan uji reliabilitas.

Pengujian validitas butir tes kompetensi pengetahuan PPKn dalam bentuk objektif pilihan ganda menggunakan rumus koefesien korelasi point biserial $\left(\mathrm{r}_{\mathrm{pbi}}\right)$, karena tes bersifat dikotomi (1 dan 0). Skor 1 diberikan pada jawaban benar untuk setiap butir soal, sedangkan skor 0 diberikan pada jawaban salah untuk setiap butir soal. Butir tes dikatakan valid apabila $r_{\text {hitung }} \geq r_{\text {tabel, }}$, sedangkan butir tes dikatakan tidak valid apabila $r_{\text {hitung }}<r_{\text {tabel }}$ Perhitungan yang dilakukan berdasarkan jumlah responden dengan taraf signifikansi $5 \%$ maka diperoleh $r_{\text {hitung }}>r_{\text {tabel }}=(0,344)$. Berdasarkan perhitungan tersebut, dari 50 butir tes yang diujikan diperoleh hasil 32 butir tes yang valid dan 18 butir tes yang tidak valid. Soal yang dinyatakan valid kemudian diuji daya beda.

Menurut Arikunto (2013:226) "Daya pembeda adalah kemampuan sesuatu soal untuk membedakan antara siswa yang pandai (berkemampuan tinggi) dengan siswa yang bodoh (berkemampuan rendah)". Berdasarkan hasil pengujian, soal yang memiliki daya pembeda cukup yaitu sebanyak 22 butir soal, soal yang memiliki daya pembeda baik sebanyak 9 butir soal dan baik sekali sebanyak 1 butir soal.

Soal yang baik adalah soal yang tidak terlalu mudah dan tidak terlalu sukar. Hasil pengujian tingkat kesukaran butir tes menunjukkan bahwa soal sukar sebanyak 2 butir, soal sedang sebanyak 20 butir dan soal mudah sebanyak 10 butir.

Uji reliabilitas dilakukan hanya pada butir soal yang telah diuji validitas butir tes dan dinyatakan valid. Berdasarkan hasil analisis uji reliabilitas perangkat tes pengetahuan PPKn, diperoleh nilai sebesar 0,92 . Sehingga $r_{11}>r_{\text {tabel }}$ yaitu $0,92>0,70$ maka tes kompetensi pengetahuan PPKn tergolong reliabel.

Setelah data kompetensi pengetahuan PPKn dikumpulkan, selanjutnya data tersebut dianalisis. Analisis data yang digunakan adalah analisis statistik inferensial. Statistik Inferensial digunakan untuk menentukan sejauh mana kesamaan antara hasil yang diperoleh dari suatu sampel dengan hasil yang akan didapat dari hasil populasi secara keseluruhan.

Sebelum dilakukan pengujian hipotesis dengan uji-t, terlebih dahulu dilakukan uji prasyarat analisis yang meliputi uji normalitas sebaran data dan uji homogenitas varians. Uji normalitas data 
dilakukan untuk mengetahui apakah uji hipotesis dengan statistik parametris dapat dilakukan atau tidak. Apabila sebaran data sudah berdistribusi normal, maka uji lanjutan dengan menggunakan statistik parametris dapat dilakukan. Untuk mengetahui apakah sebaran data kompetensi pengetahuan PPKn berdistribusi normal atau tidak, maka akan dilakukan uji normalitas data dengan menggunakan rumus Kolmogorov-Smirnov. Kriteria pengujian pada taraf signifikasi 5\% jika harga nilai maksimum $\left|F_{T}-F_{5}\right| \leq$ harga tabel Kolmogrorov-Smirnov, maka $\mathrm{H}_{0}$ diterima dan data berdistribusi normal. Sedangkan jika harga nilai $\left|F_{T}-F_{S}\right|$ maksimum $>$ harga nilai tabel Kolmogrorov-Smirnov, maka $\mathrm{H}_{0}$ ditolak dan data tidak berdistribusi normal. Uji homogenitas dapat dilakukan apabila kelompok data tersebut berdistribusi normal. Uji homogenitas varians dilakukan dengan uji F. Kriteria pengujian untuk mengetahui data yang mempunyai varians yang homogen yaitu, jika nilai $F_{\text {hitung }} \leq$ nilai $F_{\text {tabel }}$ maka sampel dinyatakan homogen. Sedangkan jika $\mathrm{F}_{\text {hitung }}>\mathrm{F}_{\text {tabel, }}$ maka sampel dinyatakan tidak homogen. Pengujian dilakukan pada taraf signifikan $5 \%$ dengan derajat kebebasan untuk pembilang $n_{1}-1$ dan derajat kebebasan untuk penyebut $n_{2}$ 1.

Analisis data dalam penelitian ini menggunakan uji-t. Rumus uji-t dengan rumus polled varians digunakan bila jumlah anggota sampel sama $\mathrm{n}_{1} \neq \mathrm{n}_{2}$ dan varians homogen. Dengan kriteria pengujian, jika $t_{\text {hitung }} \leq \mathrm{t}_{\text {tabel }}$, maka $\mathrm{H}_{\mathrm{o}}$ diterima dan $\mathrm{H}_{\mathrm{a}}$ ditolak, sebaliknya jika $\mathrm{t}_{\text {hitung }}>\mathrm{t}_{\text {tabel }}$ maka $\mathrm{H}_{\mathrm{o}}$ ditolak dan $\mathrm{H}_{\mathrm{a}}$ diterima. Pada taraf signifikansi $5 \%$ dengan $\mathrm{dk}=\mathrm{n}_{1}+\mathrm{n}_{2}-2$.

\section{ANALISIS DAN PEMBAHASAN}

Hasil analisis statistik dari data kompetensi pengetahuan PPKn siswa kelas V SD Gugus III Kecamatan Klungkung tahun ajaran 2019/2020 baik untuk kelas yang dibelajarkan menggunakan model Role Reversal Question berbantuan media Audio Visual, maupun siswa yang dibelajarkan menggunakan pembelajaran konvensional disajikan sebagai berikut. Hasil perolehan nilai yang didapatkan siswa di kelompok eksperimen dan kelompok kontrol yaitu, nilai tertinggi di kelompok ekperimen $=100$ sedangkan kelompok kontrol $=94$, dan nilai terendah dari kelompok eksperimen $=72$ sedangkan kelompok kontrol $=69$. Rata-tata nilai kelompok eksperimen yaitu 85,41 dan kelompok kontrol yaitu 81,38 .

Uji prasyarat dilakukan terlebih dahulu sebelum uji hipotesis menggunakan uji-t. Uji prasyarat tersebut meliputi uji normalitas sebaran data dan uji homogenitas varians. Hasil uji normalitas kelompok eksperimen perolehan nilai maksimum $\left|\mathrm{F}_{\mathrm{T}}-\mathrm{F}_{\mathrm{S}}\right|$ yaitu 0,12 kemudian nilai tersebut dibandingkan dengan $\mathrm{KS}_{\text {tabel }}$ Kolmogorov-Smirnov $=0$,28. Hal ini menunjukkan bahwa nilai maksimum $\left|\mathrm{F}_{\mathrm{T}}-\mathrm{F}_{\mathrm{S}}\right|<$ dari $\mathrm{KS}_{\text {tabel }}$ Kolmogorov-Smirnov, maka dapat diartikan data hasil kompetensi pengetahuan PPKn kelompok eksperimen berdistribusi normal. Sementara, hasil uji normalitas kelompok kontrol didapatkan nilai maksimum $\left|\mathrm{F}_{\mathrm{T}}-\mathrm{F}_{\mathrm{S}}\right|$ yaitu 0,12 kemudian nilai tersebut dibandingkan dengan $\mathrm{KS}_{\text {tabel }}$ Kolmogorov-Smirnov = 0,29. Hal ini menunjukkan bahwa nilai maksimum $\left|\mathrm{F}_{\mathrm{T}}-\mathrm{F}_{\mathrm{S}}\right|<$ dari $\mathrm{KS}_{\text {tabel }}$ Kolmogorov-Smirnov, maka dapat diartikan data hasil kompetensi pengetahuan PPKn kelompok eksperimen berdistribusi normal. Adapun rekapitulasi uji normalitas sebaran dara posttest disajikan dalam Tabel berikut.

Tabel 1. Rekapitulasi Hasil Uji Normalitas Sebaran Data Posttest

\begin{tabular}{|c|c|c|c|c|}
\hline Sampel Penelitian & & Nilai Maksimum |ft-fs| & $\begin{array}{l}\text { Nilai tabel } \\
\text { Kolmogorov-Smirnov }\end{array}$ & Keterangan \\
\hline Kelompok Eksperimen & 22 siswa & 0,12 & 0,28 & Berdistribusi normal \\
\hline Kelompok Kontrol & 21 siswa & 0,12 & 0,29 & Berdistribusi normal \\
\hline
\end{tabular}

Setelah diketahui data kedua kelompok berdistribusi normal, langkah selanjutnya adalah melakukan uji homogenitas varians. Uji homogenitas varians dilakukan dengan uji-F pada taraf signifikansi 5\% dengan derajat kebebasan (dk) untuk pembilang n1-1 (22 - 1 = 21) dan derajat kebebasan $(\mathrm{dk})$ untuk penyebut $\mathrm{n} 2-1(21-1=20)$ diperoleh $\mathrm{F}_{\text {tabel }}=4.08$. Berdasarkan analisis $\mathrm{F}_{\text {hitung }}=1.04$. Hal ini berarti $\mathrm{F}_{\text {hitung }}=1.04<\mathrm{F}_{\text {tabel }}=4.08$ sehingga data kedua kelompok memiliki varians yang homogen. Adapun rekapitulasi uji homogenitas varians data posttets disajikan dalam Tabel berikut.

Tabel 2. Rekapitulasi Hasil Uji Homogenitas Sebaran Data Posttest

\begin{tabular}{llllll}
\hline Sampel Penelitian & $\mathrm{dk}=\mathrm{n}-1$ & $\mathrm{~s}^{2}$ & $\mathrm{~F}_{\text {hitung }}$ & $\mathrm{F}_{\text {tabel }}$ & Keterangan \\
\hline Kelompok Eksperimen & 21 & 38,04 & \multirow{2}{*}{1,04} & \multirow{2}{*}{4,08} & \multirow{2}{*}{ Homogen } \\
Kelompok Kontrol & 20 & 36,57 & & & \\
\hline
\end{tabular}


Berdasarkan hasil uji prasyarat analisis diketahui bahwa data kedua kelompok berdistribusi normal dan memiliki varians yang homogen, maka selanjutnya dilakukan pengujian hipotesis untuk menjawab rumusan masalah pada penelitian dengan uji-t polled varians. Kriteria pengujian hipotesis yaitu jika $t_{\text {hitung }} \leq t_{\text {tabel }}$, maka $\mathrm{H}_{\mathrm{o}}$ diterima, dan jika $t_{\text {hitung }}>\mathrm{t}_{\text {tabel }}$ maka $\mathrm{H}_{\mathrm{o}}$ ditolak. Pada taraf signifikansi $5 \%$ dengan $\mathrm{dk}=\mathrm{n}_{1}+\mathrm{n}_{2}-2$. Rekapitulasi hasil uji hipotesis dipaparkan dalam tabel berikut.

Tabel 3. Rekapitulasi Hasil Uji Hipotesis

\begin{tabular}{lllllll}
\hline Sampel Penelitian & Rata-rata & Varians & Dk & $t_{\text {hitung }}$ & $t_{\text {tabel }}$ & Kesimpulan \\
\hline Kelompok Eksperimen & 85,41 & 38,04 & \multirow{2}{*}{41} & \multirow{2}{*}{2,166} & \multirow{2}{*}{2,019} & \multirow{2}{*}{$\mathrm{H}_{0}$ ditolak } \\
Kelompok Kontrol & 81,38 & 36,57 & & & & \\
\hline
\end{tabular}

Berdasarkan hasil uji hipotesis kompetensi pengetahuan PPKn kelompok eksperimen dan kelompok kontrol diperoleh $t_{\text {hitung }}=2.166$ pada taraf signifikansi $5 \%$ dengan dk $=\mathrm{n} 1+\mathrm{n} 2-2=22+21-2$ $=41$ menunjukkan nilai $t_{\text {tabel }}=2.019$ sehingga $t_{\text {hitung }}>t_{\text {tabel }}(2.166>2.019)$, maka $H_{o}$ ditolak dan $H_{a}$ diterima sehingga terdapat perbedaan yang signifikan kompetensi pengetahuan PPKn antara kelompok siswa yang dibelajarkan menggunakan model pembelajaran Role Reversal Question berbantuan Media Audio Visual dengan kelompok siswa yang dibelajarkan menggunakan pembelajaran konvensional pada kelas V SD Gugus III Kecamatan Klungkung Tahun Ajaran 2019/2020. Perolehan perhitungan nilai ratarata antara kelompok siswa yang dibelajarkan menggunakan model pembelajaran Role Reversal Question berbantuan Media Audio Visual dengan kelompok siswa yang dibelajarkan secara konvensional menunjukkan bahwa terdapat perbedaan nilai rata-rata sebesar 4,03. Nilai rata-rata yang diperoleh siswa pada kelompok eksperimen lebih besar yaitu 85,41 sedangkan nilai rata-rata yang diperoleh siswa pada kelompok kontrol yaitu 81,38. Dengan demikian, model pembelajaran Role Reversal Question berbantuan Media Audio Visual berpengaruh terhadap kompetensi pengetahuan PPKn siswa kelas V SD Gugus III Kecamatan Klungkung Tahun Ajaran 2019/2020.

Hasil temuan menunjukkan bahwa kedua kelompok sampel penelitian memiliki kemampuan awal yang setara, setelah diberikan perlakuan berupa pembelajaran menggunakan model pembelajaran Role Reversal Question berbantuan Media Audio Visual pada kelompok eksperimen dan pembelajaran konvensional pada kelompok kontol diperoleh hasil yang berbeda. Perbedaan tersebut terlihat dari nilai rata-rata posttest siswa yang mengikuti pembelajaran menggunakan model pembelajaran Role Reversal Question berbantuan Media Audio Visual lebih tinggi dibandingkan dengan nilai rata-rata posttest siswa yang mengikuti pembelajaran konvensional.

Dalam kelompok eksperimen, kegiatan pembelajaran dalam muatan materi PPKn menggunakan model pembelajaran Role Reversal Question berbantuan media Audio Visual berjalan dengan kondusif dan optimal. Ada beberapa keunggulan dari model Role Reversal Question ini yaitu, Proses belajar mengajar berpusat pada siswa sehingga menjadikan siswa lebih aktif dalam pembelajaran karena siswa terlibat langsung dalam proses pembelajaran tersebut. Proses pembelajaran menarik, sebab siswa tidak hanya mendengar penjelasan dari guru saja tetapi juga mengalami kejadian tersebut. Melatih keberanian siswa dalam bertanya dan menjawab pertanyaan. Serta Menciptakan kerjasama antar siswa dalam kegiatan pembelajaran. Model Role Reversal Question berbantuan media Audio Visual dapat meningkatkan kompetensi pengetahuan siswa terutama pada kompetensi pengetahuan PPKn. Role reversal question merupakan suatu model pembelajaran yang memberikan kesempatan para siswa untuk bertukar peran menjadi guru sehingga setiap siswa akan tertantang dan berlatih menjelaskan permasalahan kepada teman-temannya" (Silberman, 2007:149). Kegiatan tanya jawab dapat membantu siswa untuk memperoleh pengetahuan, keterampilan dan keaktifan dalam belajar. Melalui proses tanya jawab dapat memudahkan siswa untuk memahami materi dan menjadikan siswa lebih aktif. Melalui model ini juga, siswa dapat berpartisipasi secara langsung tidak hanya mendengarkan penjelasan materi yang di sampaikan oleh guru namun juga berfikir kritis dalam tanya jawab mengenai materi pembelajaran yang dipelajari.

Pada kelompok kontrol, siswa dibelajarkan dengan pembelajaran konvensional atau pembelajaran yang biasa dilaksanakan oleh wali kelas. Secara teoritis pembelajaran yang menggunakan model konvensional merupakan proses belajar mengajar dengan cara tradisional atau sering dikatakan sebagai metode ceramah, karena sejak dulu metode ini telah dijadikan sebagai alat komunikasi lisan antara guru dengan siswa dalam proses belajar mengajar. Hal ini menyebabkan siswa menjadi kurang semangat untuk mengikuti proses pembelajaran yang berlangsung, dan cepat bosan mengikuti pembelajaran.

Keberhasilan penggunaan model pembelajaran Role Reversal Question berbantuan media Audio Visual juga didukung oleh hasil penelitian yang dilakukan oleh Sari (2018). Berdasarkan hasil penelitian menunjukkan bahwa model Role Reversal Questions (bertukar peran membuat pertanyaan) berpengaruh 
terhadap hasil belajarsiswa kelas V pada mata pelajaran PKn di SD Ngugus V Kecamatan Cakranegara tahun pelajaran 2017/2018. Dan penelitian yang dilakukan oleh Indriani (2015) menyimpulkan bahwa pembelajaran PKn menggunakan model active learning tipe role reversal question dapat meningkatkan hasil belajar peserta didik kelas V SDN Minomartani 6 Sleman Yogyakarta.

\section{KESIMPULAN}

Dari hasil analisis data dan pembahasan yang telah dipaparkan, maka dapat disimpulkan yaitu sebagai berikut. Sesuai dengan hasil analisis data posttest menunjukkan bahwa nilai rata-rata kelompok eksperimen lebih tinggi dari kelompok kontrol. Hal ini membuktikan bahwa terdapat perbedaan yang signifikan kompetensi pengetahuan PPKn antara kelompok siswa yang dibelajarkan menggunakan model pembelajaran Role Reversal Question berbantuan Media Audio Visual dengan kelompok siswa yang dibelajarkan menggunakan pembelajaran konvensional. Jadi dapat disimpulkan bahwa model pembelajaran Role Reversal Question berbantuan Media Audio Visual berpengaruh terhadap kompetensi pengetahuan PPKn pada siswa kelas V SD Gugus III Kecamatan Klungkung Tahun Ajaran 2019/2020. Sebagai tindak lanjut dari hasil penelitian, maka disarankan kepada: (1) Guru yaitu, hasil dari penelitian ini dapat memberikan masukan kepada guru didalam merancang kegiatan belajar yang menyenangkan dan inovatif bagi siswa dengan mempergunakan model pembelajaran Role Reversal Question berbantuan media Audio Visual terhadap kompetensi pengetahuan PPKn guna mengingkatkan kualitas proses dan hasil pembelajaran. (2) Kepala Sekolah yaitu, hasil penelitian ini dapat memberikan masukan bagi kepala sekolah agar dapat dijadikan pedoman bagi sekolah dan pendukung sumber belajar bagi guru sehingga dapat menciptakan mutu dan kualitas pembelajaran di sekolah. (3) Peneliti lain, Hasil penelitian ini disarankan agar dapat dijadikan referensi bagi peneliti lain yang melakukan penelitian terkait model pembelajaran Role Reversal Question berbantuan media Audio Visual dan dapat mengembangkan penelitian selanjutnya.

\section{DAFTAR PUSTAKA}

Agung, A.A. Gede. 2014. Metodologi Penelitian Pendidikan. Yogyakarta: Aditya Media Publishing.

Arikunto, Suharsimi. 2013. Prosedur Penelitian: Suatu Pendekatan Praktik: Jakarta: Rineka Cipta.

Dantes, Nyoman. 2012. Metode Penelitian. Yogyakarta: Andi.

Indriani, Marsiyanti. 2015. Upaya Meningkatkan Hasil Belajar PKn Menggunakan Model Active Learning Tipe Role Reversal Question Pada Siswa Kelas V SD N Minomartani 6 Sleman Yogyakarta. Tersedia pada http://eprints.uny.ac.id/16546/1/Marsiyanti\%20Indriani.pdf diakses pada 28 November 2019.

Murti, Ambar Susilo. 2016. Peningkatan Hasil Belajar PKn Kelas V Melalui Model Active Learning (tipe role reversal question) SDN 4 Doplang Kecamatan Jati Kabupaten Blora. Premiere Educantum. Jurnal Pendidikan Dasar dan Pembelajaran.

Sari, Mei Patmala. 2018. Pengaruh Model Role Reversal Questions (Bertukar Peran Membuat Pertanyaan) Terhadap Hasil Belajar Siswa Kelas V Pada Mata Pelajaran PKn Di SDN Gugus V Kecamatan Cakranegara Tahun Pelajaran 2017/2018. Tersedia pada http://eprints.unram.ac.id/6133/1/Jurnal\%20Skripsi\%20Mei\%20Patmala\%20Sari.pdf diakses pada 15 November 2019.

Setyosari, Punaji. 2015. Metode Penelitian Pendidikan dan Pengembangan Edisi ke Empat. Jakarta: Prenadamedia Group.

Setyosari, Punaji. 2012. Metode Penelitian Pendidikan dan Pengembangan. Jakarta: Kencana.

Silberman, Melvin. L. 2007. Active Learning 101 Cara Belajar Siswa Aktif. Nusamedia, Bandung.

Sugiyono. 2018. Metode Penelitian Pendidikan Pendekatan Kuantitatif, Kualitatif dan R\&D. Bandung: Alfabeta. 
Supradnyana, Km. Wahyu. 2016. Pengaruh Model Pembelajaran Discovery Learning Berbantuan Media Audio Visual Terhadap Hasil Belajar IPA Kelas IV. Jurnal Mimbar PGSD Universitas Pendidikan Ganesha Vol:4 No: $\quad 1 . \quad$ Tersedia pada http//ejournal.undiksha.ac.id/index.php/JJPGSD/article/ViewFile/7390/5043 (diakses tanggal 10 November 2019).

Tegeh, I Made \& I Made Kirna. 2010. Metode Penelitian Pengembangan Pendidikan. Singaraja: Universitas Pendidikan Ganesha.

Undang-Undang Republik Indonesia Nomor 20 Tahun 2003 tentang Sistem Pendidikan Nasional, 2003. Jakarta: Departemen Pendidikan Nasional.

Warsono dan Hariyanto. 2012. Pembelajaran Aktif Teori dan Asesmen. Bandung: PT Remaja Rosdakarya. 